\title{
Recent advances in our understanding of the primate
}

\section{corticospinal system [version 1; peer review: 2 approved]}

\section{Roger Lemon (iD)}

Department of Clinical and Motor Neuroscience, Queen Square Institute of Neurology, Box 28 National Hospital, Queen Square, London, WC1N 3BG, UK

V1 First published: 11 Mar 2019, 8(F1000 Faculty Rev):274

https://doi.org/10.12688/f1000research.17445.1

Latest published: 11 Mar 2019, 8(F1000 Faculty Rev):274

https://doi.org/10.12688/f1000research.17445.1

\section{Abstract}

The last few years have seen major advances in our understanding of the organisation and function of the corticospinal tract (CST). These have included studies highlighting important species-specific variations in the different functions mediated by the CST. In the primate, the most characteristic feature is direct corticomotoneuronal (CM) control of muscles, particularly of hand and finger muscles. This system, which is unique to dexterous primates, is probably at its most advanced level in humans. We now know much more about the origin of the CM system within the cortical motor network, and its connectivity within the spinal cord has been quantified. We have learnt much more about how the CM system works in parallel with other spinal circuits receiving input from the CST and how the CST functions alongside other brainstem motor pathways. New work in the mouse has provided fascinating insights into the contribution of the CM system to dexterity. Finally, accumulating evidence for the involvement of CM projections in motor neuron disease has highlighted the importance of advances in basic neuroscience for our understanding and possible treatment of a devastating neurological disease.

\section{Keywords}

primate, corticospinal, cortex, motor, movement, dexterity, tool-use, ALS

\section{Open Peer Review}

Approval Status

1 2

version 1

11 Mar 2019

Faculty Reviews are review articles written by the prestigious Members of Faculty Opinions. The articles are commissioned and peer reviewed before publication to ensure that the final, published version is comprehensive and accessible. The reviewers who approved the final version are listed with their names and affiliations.

1. Eric Schmidlin, University of Fribourg,

Fribourg, Switzerland

2. Robert J. Morecraft, University of South

Dakota, Vermillion, USA

Any comments on the article can be found at the end of the article. 
Corresponding author: Roger Lemon (r.lemon@ucl.ac.uk)

Author roles: Lemon R: Conceptualization, Data Curation, Formal Analysis, Funding Acquisition, Investigation, Methodology, Project Administration, Resources, Software, Supervision, Validation, Visualization, Writing - Original Draft Preparation, Writing - Review \& Editing

Competing interests: No competing interests were disclosed.

Grant information: This work was supported by past Wellcome Trust funding.

The funders had no role in study design, data collection and analysis, decision to publish, or preparation of the manuscript.

Copyright: @ 2019 Lemon R. This is an open access article distributed under the terms of the Creative Commons Attribution License, which permits unrestricted use, distribution, and reproduction in any medium, provided the original work is properly cited.

How to cite this article: Lemon R. Recent advances in our understanding of the primate corticospinal system [version 1; peer review: 2 approved] F1000Research 2019, 8(F1000 Faculty Rev):274 https://doi.org/10.12688/f1000research.17445.1

First published: 11 Mar 2019, 8(F1000 Faculty Rev):274 https://doi.org/10.12688/f1000research.17445.1 
The cortico-motoneuronal $(\mathrm{CM})$ system is unique to dexterous primates. It provides a direct pathway from motor cortex to the alpha motoneuron. It has long been associated with skilled use of the hands and with tool-making in particular' ${ }^{1}$. Recent advances have allowed a better definition of its origin within the cortical network and its connectivity within the spinal cord.

\section{'New' M1: the origin of the cortico-motoneuronal output}

We know from the work of Rathelot and Strick $^{2,3}$, using retrograde transneuronal tracers, that in the macaque monkey, $\mathrm{CM}$ neurons are found in two main cortical areas: 'new' M1 and area 3a, part of primary somatosensory cortex (S1). Primary motor cortex (M1) is the same as Brodmann area 4; Rathelot and Strick coined the term 'new' M1 to define the caudal area of M1 which is restricted to the anterior bank of the central sulcus; very few CM neurons were found more rostrally in the 'old' M1 region, on the convexity of the gyrus. This rostral region also gives rise to corticospinal projections, projections that do not terminate on motoneurons, and it also projects to the pontine nuclei and brainstem centres, giving rise to descending motor pathways, including the reticulospinal tract ${ }^{4}$. Witham et al..$^{5}$ used single intracortical stimuli to activate 'new' versus 'old' M1 in anaesthetised macaques. Then the authors made intracellular recordings from forelimb and hand motoneurons and found some fast, short-latency monosynaptic responses from 'new' M1; no such responses were found from 'old' M1. Long-latency monosynaptic excitation, presumably mediated by more slowly conducting $\mathrm{CM}$ neurons, was far more common. We know that CM cells have a wide range of soma sizes ${ }^{2}$ and are certainly not derived solely from the largest (Betz) cells. Long-latency monosynaptic effects were evoked from both regions of M1, as were other more complex, oligosynaptic effects.

The extent of the CM projection in humans, which has been investigated by using non-invasive cortical stimulation ${ }^{6,7}$, may well be more widespread than in non-human primates. For example, there is new evidence for a $\mathrm{CM}$ projection from ventral premotor cortex in humans ${ }^{8}$, which in macaques gives rise to corticospinal but not $\mathrm{CM}$ projections.

\section{Quantification of the cortico-motoneuronal output}

In 2013, the extent of the CM projection from the hand area of primary motor cortex was quantified by Morecraft et al. ${ }^{9}$. They first identified the hand/arm regions of macaque M1 by intracortical microstimulation (ICMS) and then made injections of anterograde tracers into the cortex close to the central sulcus, and much of the injection site involved the anterior bank of the sulcus. After a recovery period, they sacrificed the animals and carried out a detailed stereological analysis of labelled boutons in the contralateral and ipsilateral spinal cord, analysing tissue taken from C5 to T1 spinal segments. The main conclusions were that almost all labelled boutons (98\%) were found in the contralateral cord. This agrees with the finding that stimulation of the pyramidal tract on one side rarely evokes any postsynaptic effects on upper limb motoneurons ${ }^{10}$. Fibres from hand/arm M1 that terminated contralaterally gave only sparse labelling in the dorsal horn laminae. The largest proportion of contralateral labelled boutons was in lamina VII (59\%), confirming a heavy projection to the intermediate zone. However, the second highest proportion of boutons was found amongst the motor nuclei of lamina IX (18\%), suggesting that the CM projection is a very significant component of the total corticospinal projection, influencing motoneurons innervating flexors acting on the shoulder and elbow rostrally (C5-C7), along with flexors, extensors, abductors and adductors acting on the digits, hand and wrist caudally (C8-T1). It should be stressed that these motoneurons have widespread dendritic trees that extend well into the intermediate zone, including lamina VII ${ }^{11}$, which could mean that many of the boutons in that lamina labelled after M1 injections are still CM boutons, terminating on proximal dendrites of target motoneurons.

A somewhat different picture emerges for the corticospinal projection from the leg area of M1, where around $10 \%$ of the fibres terminate ipsilaterally, especially among motoneurons of more proximal leg muscles, confirming a number of physiological studies showing bilateral effects on the lower limb ${ }^{12}$.

Rather than defining a neuron by a single target with which its axon establishes a synaptic connection (for example, projection to spinal motoneurons), one should recognize that most central nervous system neurons have axons which arborise to contact multiple targets, the sum of which represents the neuron's 'connectome'. To date, most of this work has involved rodents, in which it is possible to use genetic manipulations to recognize all parts of a neuron's connectome. There is some evidence that the corticospinal connectome is more restricted in primates than in rodents; for example, the cortico-striatal projection appears to be separate from the corticospinal projection in macaques but is shared in rodents ${ }^{13}$. Again, in primates, a significant part of the corticopontine projection is quite separate from the corticospinal projection, which is much less marked in rodents ${ }^{14}$.

\section{Functional relationship between cortico- motoneuronal cell activity and target muscles}

Although CM cells have been identified in many different studies, using the method of spike-triggered averaging ${ }^{15,16}$, the contribution made by $\mathrm{CM}$ cell discharge to the activity of its target muscles, and the postures and movements in which those muscles are recruited, is far from simple ${ }^{17}$. Whereas approaches to the analysis of populations of motor cortical activity have become more and more sophisticated, how these dynamic representations lead to precise patterning of muscle output is not clear.

Some CM cells do appear to behave like 'upper motoneurons' in that their activity closely parallels that of their target muscles ${ }^{18,19}$. However, in many cases, CM cell activity can be clearly dissociated from that of their target muscles ${ }^{17-19}$. So, for example, Muir and Lemon $^{20}$ showed that macaque CM cells facilitating intrinsic hand muscles showed strong task-specific effects and that both CM cell and target muscle were active during one task (precision grip) but not during another (power grip). In the latter task, the CM cell was deactivated while the muscle was still active and therefore clearly driven by inputs other than the CM cell being tested. 
CM cells rarely facilitate single muscles, and most have a complex 'muscle field' which often includes a number of functional synergists ${ }^{15,21,22}$. In a recent study, Griffin et al. ${ }^{22}$ recorded CM cells during performance of a forelimb task in which it is possible to dissociate cortical activity which is 'muscle-like' (that is, resembles the timing and pattern of muscle activity) from that which is 'extrinsic-like' (that is, resembles the direction of movement produced, independent of arm posture). They found that nearly all of $40 \mathrm{CM}$ cells investigated were 'muscle-like'. However, it was relatively uncommon for a CM cell to exhibit a pattern of activity similar to that of its target muscle when this was employed as a simple agonist. These authors concluded that the broad distribution of the cell-target muscle vectors, found during performance of the task in three different forearm postures, were such that agonist, synergist, fixator and antagonist functions of target muscles were each well represented by the activity of different CM cells. Indeed, CM outputs organised along these lines show how this system operates to provide a great deal of functional flexibility in the manner of muscle recruitment, a flexibility that cannot be afforded by the relatively fixed synergies represented in spinal motor mechanisms.

Joint fixation can be achieved by co-contraction of antagonistic muscle groups and is crucial for stabilisation of the long, bony articulatory chain from proximal arm to distal phalanx $x^{23}$. The role of the CM system as a muscle fixator has probably been underplayed compared with its role during dynamic, individuated movements. However, many CM cells show sustained activity during the 'hold' period of motor tasks ${ }^{18,24}$ and so their inputs may be important for maintaining the muscle set for that task.

Studies looking at the natural activity of CM cells are still needed to understand how they contribute to the executed movement. Old-fashioned electrical or modern optogenetic stimulation are extremely useful adjuncts to this approach but cannot simulate the natural activity of CM cells. For example, recent work suggests that long trains of ICMS, rather than simulating motor cortex output, give misleading accounts of motor organisation because they 'hijack' intracortical circuits and override normal patterns of CM output ${ }^{25}$.

Even single intracortical shocks can evoke high-frequency, repetitive firing from corticospinal neurons ${ }^{26}$. Therefore, the results are possibly more difficult to interpret than the effects seen in spiketriggered averages based on the natural, movement-related discharge of CM cells. Nevertheless, careful use of single-pulse ICMS by Cheney et al. has been important in determining the complex maps of muscle outputs in primary ${ }^{27,28}$ and secondary ${ }^{29,30}$ motor areas. These studies have helped to demonstrate the direct, short-latency influence of M1 over forelimb muscles, compared with slower effects evoked from secondary motor areas.

\section{Fast and slow conduction in the corticospinal tract}

The primate corticospinal tract (CST) is remarkable in displaying a 100-fold range of axon diameters ${ }^{31}$. Most mammals have a very large number of small corticospinal fibres, ranging from around $3 \mu \mathrm{m}$ to as small as $0.5 \mu \mathrm{m}^{4,32}$. Larger primates (including the macaque, spider monkey, gibbon and human) also possess largediameter fibres, up to around $12 \mu \mathrm{m}$ in macaques and up to
$22 \mu \mathrm{m}$ in humans. Body size alone is clearly not the key factor since much larger mammals such as cows and whales have relatively small corticospinal fibres. A number of different explanations have been put forward for large, fast axons in primates, including the branching pattern of the 'connectome', the need to maintain high firing rates, and the importance of reducing conduction delays during transitions from movement to posture in skilled $\operatorname{grasp}^{33,34}$.

These fast fibres are very much in the minority, comprising a small percentage of the total, but with an importance out of all proportion to their numbers. (It has been estimated that, in the macaque tract with around 600,000 fibres, about 18,000 fibres have diameters greater than $3 \mu \mathrm{m}^{31}$.) The larger fibres are particularly vulnerable to disease and trauma (for example, during spinal cord injury $)^{35,36}$. M1 gives rise to some of the fastest fibres, and there is a bias towards faster fibres from 'new' versus 'old' M1 $1^{5,37}$. Long-latency monosynaptic effects generated by M1 stimulation ${ }^{5}$ had latencies up to around three or four times longer than that of the fastest CM effects, so if these fastest effects were conducted by axons with conduction velocities around $70 \mathrm{~m} / \mathrm{s}$, the slowest effects would derive from axons conducting at around $17 \mathrm{~m} / \mathrm{s}$, still well above the velocity $(\sim 7 \mathrm{~m} / \mathrm{s})$ for the median axon diameter of M1 corticospinal neurons of around $1.2 \mu \mathrm{m}^{37}$.

There is a problem in understanding the function of the slowest fibres; they are largely missing from neurophysiological studies in primates using antidromic activation of CST neurons from the pyramidal $\operatorname{tract}^{5,31,38}$, and there are a number of possible explanations for this ${ }^{39}$. Until a better means of electrophysiologically identifying the neurons giving rise to the slowest CST fibres can be found, the function of these slow neurons will remain a mystery.

\section{The cortico-motoneuronal system in the wider context of cortical control of movement}

It has been emphasised that the CM system does not work alone but rather in concert with other descending and spinal segmental systems ${ }^{40,41}$. Nevertheless, there is accumulating evidence that the $\mathrm{CM}$ system adds the characteristic capacity for skilled hand movements, including the 'individuation' of finger movements ${ }^{40}$. Early, classic studies showed that complete pyramidotomy permanently abolished relatively independent finger movements (RIFMs) ${ }^{42-44}$. However, if the pyramidotomy was incomplete, there was often substantial recovery ${ }^{43}$, suggesting that sparing a relatively small proportion of the total corticospinal and CM outflow can be the basis of a return of hand function.

Interruption of the lateral (crossed) CST at different spinal cervical levels also abolishes RIFM, but again there is some degree of recovery ${ }^{45,46}$. Since corticospinal fibres make many different types of connections within the spinal cord, it is a continuing challenge to determine which of them makes critical contributions to RIFM. In addition to their CM connections, CST fibres give rise to inputs to $\mathrm{C} 3-\mathrm{C} 4$ propriospinal neurons which send descending projections to forelimb motoneurons located in the lower cervical segments. CST fibres exert further indirect excitatory and inhibitory effects via interneurons in 
these same lower segments, and these interneurons appear to receive the bulk of corticospinal input from $\mathrm{M}^{9}$. A lesion of the lateral CST at the mid-cervical level interrupts all of the CM and other corticospinal inputs to lower cervical segments but leaves the descending axons of $\mathrm{C} 3-\mathrm{C} 4$ propriospinal neurons intact $^{45}$. It is noteworthy that such a lesion results in a devastating initial loss of the precision grip needed by the monkey to retrieve small rewards ${ }^{45,47,48}$. This is consistent with the notion that the CM system plays a major role in the execution of precision grip in the intact animal.

After this initial deficit, recovery occurs over a period of a few weeks. This recovery has been shown to involve the C3-C4 system ${ }^{45,47,48}$. It has also been demonstrated that, although precision grip performance returns to control levels, there are subtle differences in the pattern of electromyographic activity, suggesting that changes in control have taken place to compensate for the loss of CM inputs ${ }^{45}$.

Damage to the human motor cortex and CST is generally far more devastating than in animal models and this may be because the $\mathrm{CM}$ system is best developed in humans ${ }^{40}$. Interestingly, classic studies of the effects of mid-cervical cordotomy for pain relief in humans showed that lesions of the lateral funiculus which avoided the CST but which would have interrupted more ventrally located propriospinal fibres did not affect the function of upper limb movement ${ }^{49}$.

An important study by Zaaimi et al..$^{10}$ showed that recovery after pyramidal lesions probably involves marked upregulation in reticulospinal control of hand motor nuclei. In the intact macaque, these inputs overlap with those from the corticospinal system $^{50}$, although they are significantly weaker. However, 6 months after a unilateral pyramidal lesion, there were considerably higher levels of reticulospinal excitation of forelimb flexor and intrinsic hand motoneurons ${ }^{10}$, which may well contribute to the recovery of crude grasp after a pyramidal lesion or cortical stroke ${ }^{51}$. These results are of great importance in trying to disentangle the positive and negative motor signs after a stroke in humans and in designing new therapies to enhance the reticulospinal contribution to recovery of hand function ${ }^{52}$.

\section{The cortico-motoneuronal system, dexterity, and new findings from the mouse}

$\mathrm{CM}$ connections are particularly well developed in dexterous, tool-using primates. In a recent study, Quallo et al. ${ }^{24}$ demonstrated that macaque corticospinal neurons, including some $\mathrm{CM}$ cells, were just as active during tool use, involving use of a rake to retrieve food rewards, as they were during a precision grip. It might well be expected that the same neurons that are involved in control of skilled hand and finger movements are also recruited during tool use; this study was the first to demonstrate that to be the case.

Rodents do not possess CM connections, and their manipulative skills have developed along quite different lines, well suited to their ecological niche. Because of the methodological advantages of using the rat (and particularly the mouse) for the genetic dissection of neural control systems, a number of studies have sought to model grasp in rats or mice by training them to retrieve small pellets with the forepaw. These studies generally show that, even after training, rodents generally achieve quite low levels of success on such tasks, often around 50 to $60 \%$ (for example, 53,54). It is important to stress the fundamental difference between precision grip in the Old World primate, such as the macaque, and the grasp executed by rodents. It is noteworthy that macaques can be trained to perform precision grip at success rates close to $100 \%$.

Of course, it would be very interesting if 'dexterity' in rodents could be improved by supplementing their forepaw control system with $\mathrm{CM}$ connections. A fascinating piece of recent research has achieved just this ${ }^{54}$. This study took advantage of the fact that CM connections, though absent in adult rodents, are transiently present in the neonatal animal, before being withdrawn in the early postnatal period ${ }^{54,56}$. Gu et $a l .^{54}$ sought to interfere genetically with the plexin-based signalling system involved in withdrawal of CM projections. They developed a PlexA1 mutant in which CM connections established at birth are maintained into adulthood. Other descending pathways were not affected. Using ICMS, the authors demonstrated that these mutants had a fast motor pathway from motor cortex to forelimb muscles, which was lacking in the wild-type mouse. They also showed that the mutant mice could be trained to perform a pellet-grasping task at higher levels of success than wild-type animals. Because other descending pathways were not changed in the mutants, this lends further support to a main role for the corticospinal system in enhancing skilled grasp.

A further fascinating part of this discovery was to demonstrate the existence of a CIS-regulatory system in layer V of motor cortex that inhibits the Plexin signalling and thereby allows CM connections, all of which are derived from layer $\mathrm{V}$ corticospinal neurons, to be maintained into adulthood. The authors showed that this inhibitory system is strongly expressed in motor cortex of dexterous primates such as human, chimpanzee, orangutan and baboon but is not present in other less dexterous primates, such as marmoset and bushbaby, or in rats or mice ${ }^{54}$.

\section{The cortico-motoneuronal system and motor neuron disease}

Although the involvement of the CST in motor neuron disease (amyotrophic lateral sclerosis, or ALS) was known from the earliest descriptions of the disease, accumulating evidence now suggests an especially important role for the CM component of the corticospinal system in some forms of ALS ${ }^{57,58}$. For example, a distinctive feature in the early stages of ALS in some patients is the 'split-hand' syndrome, in which there is much greater weakness and wasting of the muscles acting on the radial side of the hand (moving the thumb and index finger) than on the ulnar side (hypothenar muscles, acting on the little finger).

The main cause of this striking contrast does not appear to be ALS-related pathology in the peripheral neuromuscular system but rather a TDP43 pathology acting on the CM projection. It is well known that there is a disproportionately large 
representation of thumb movements in M1, and electrophysiological studies in both non-human primates ${ }^{1,59}$ and humans ${ }^{6,7}$ have shown that the largest monosynaptic excitation following corticospinal activation is found in intrinsic thumb and index finger muscles, and there are weaker effects on the hypothenar musculature. In early stages of the disease, the impact on CM projections results in specific, task-related deficits, including use of the thenar hand for a multitude of manipulative skills, including writing, typing and doing up buttons.

More widely, ALS pathology involving CM projections might affect skilled aspects of locomotion ${ }^{60}$ and speech $^{58}$. It is noticeable that $\mathrm{CM}$ projections to the nucleus ambiguus, which innervates the laryngeal musculature, are present in humans but not in monkeys ${ }^{61}$.

Braak et al. have gathered evidence that the early stages of ALS involve TDP43 pathology in cortical layer $\mathrm{V}$ pyramidal neurons with long axons projecting to subcortical and spinal targets ${ }^{62}$. It has been suggested that the TDP43 pathogen is transmitted via these long axons to all target motoneurons of the CM system, which in turn results in the 'lower motoneuron' signs characteristic of ALS. Interestingly, recent evidence suggests that primate pyramidal neurons have membrane properties quite different from those in the rodent, including high expression levels of the fast potassium channel, Kv3.1b, which is not found in rat pyramids ${ }^{63}$. This difference, and probably others, might contribute to the vulnerability of the TDP43 pathology in primates, explaining why the cortical stages of ALS have been more difficult to demonstrate in the rodent $^{62}$. Understanding the speciesspecific properties of the primate $\mathrm{CM}$ system might provide a valuable model for understanding and treating ALS.

\section{Conclusions and prospects}

The CM system is unique to primates and particularly well developed in humans. It provides a fast, direct pathway to motoneurons, particularly those supplying muscles that subserve some of the most characteristic human hand movements, including those for tool use, music making, gesture and communication. $\mathrm{CM}$ control signals effectively bypass the more rigid networks provided by spinal segmental connectivity and support a much richer repertoire of grasping movements, based on the combination and recombination of many different $\mathrm{CM}$ outputs to hand and digit muscles. Although our knowledge of the organisation of this system is now much improved, we still need to know more about its functional contributions to skilful movement. In animal studies, a better definition of the molecular and genetic identity of the CM system might provide further clues, including the possibility of a selective CM cell blocker which might give further insights into not only $\mathrm{CM}$ function but the recovery process involving other systems. Selective tools that could be used to repair or promote the $\mathrm{CM}$ system could be used in therapeutic studies.

\section{Grant information}

This work was supported by past Wellcome Trust funding.

The funders had no role in study design, data collection and analysis, decision to publish, or preparation of the manuscript.

\section{Acknowledgement}

I should like to acknowledge the many colleagues and collaborators who have contributed to the research highlighted in this review.
1. Porter R, Lemon RN: Corticospinal function and voluntary movement Physiological Society Monograph, Oxford: Clarendon Press. 1993. Reference Source

2. $F$ Rathelot JA Strick PL. Muscle representation in the macaque motor cortex: An anatomical perspective. Proc Natl Acad Sci U S A. 2006; 103(21): 8257-62. PubMed Abstract | Publisher Full Text | Free Full Text | F1000 Recommendation

3. F Rathelot JA, Strick PL: Subdivisions of primary motor cortex based on cortico-motoneuronal cells. Proc Natl Acad Sci U S A. 2009; 106(3): 918-23. PubMed Abstract | Publisher Full Text | Free Full Text | F1000 Recommendation

4. Kuypers HG: Anatomy of the descending pathways. In: Handbook of Physiology - The Nervous System II. (Brookhart JM, Mountcastle VB, eds), Bethesda, MD: American Physiological Society. 1981; 597-666. Publisher Full Text

5. F Witham CL, Fisher KM, Edgley SA, et al:: Corticospinal Inputs to Primate Motoneurons Innervating the Forelimb from Two Divisions of Primary Motor Cortex and Area 3a. J Neurosci. 2016; 36(9): 2605-16. PubMed Abstract | Publisher Full Text | Free Full Text | F1000 Recommendation

6. Palmer E, Ashby P: Corticospinal projections to upper limb motoneurones in humans. J Physiol. 1992; 448: 397-412.

PubMed Abstract | Publisher Full Text | Free Full Text

7. de Noordhout AM, Rapisarda G, Bogacz D, et al:: Corticomotoneuronal synaptic connections in normal man: an electrophysiological study. Brain. 1999; 122(Pt 7): 1327-40.

PubMed Abstract | Publisher Full Text

8. Fornia L, Ferpozzi V, Montagna M, et al.: Functional Characterization of the Left Ventrolateral Premotor Cortex in Humans: A Direct Electrophysiological Approach. Cereb Cortex. 2018; 28(1): 167-83.

PubMed Abstract | Publisher Full Text
9. F Morecraft RJ, Ge J, Stilwell-Morecraft KS, et al.: Terminal distribution of the corticospinal projection from the hand/arm region of the primary motor cortex to the cervical enlargement in rhesus monkey. J Comp Neurol. 2013; 521(18): 4205-35.

PubMed Abstract | Publisher Full Text | Free Full Text | F1000 Recommendation

10. F Zaaimi B, Edgley SA, Soteropoulos DS, et al.: Changes in descending motor pathway connectivity after corticospinal tract lesion in macaque monkey. Brain. 2012; 135(Pt 7): 2277-89.

PubMed Abstract | Publisher Full Text | Free Full Text | F1000 Recommendation

11. Lawrence DG, Porter R, Redman SJ: Corticomotoneuronal synapses in the monkey: light microscopic localization upon motoneurons of intrinsic muscles of the hand. J Comp Neurol. 1985; 232(4): 499-510. PubMed Abstract | Publisher Full Text

12. $\mathrm{F}$ Lacroix $\mathrm{S}$, Havton LA, McKay $\mathrm{H}$, et al.: Bilateral corticospinal projections arise from each motor cortex in the macaque monkey: a quantitative study. J Comp Neurol. 2004; 473(2): 147-61.

PubMed Abstract | Publisher Full Text | F1000 Recommendation

13. Turner RS, DeLong MR: Corticostriatal activity in primary motor cortex of the macaque. J Neurosci. 2000; 20(18): 7096-108.

PubMed Abstract | Publisher Full Text

14. Ugolini G, Kuypers HG: Collaterals of corticospinal and pyramidal fibres to the pontine grey demonstrated by a new application of the fluorescent fibre labelling technique. Brain Res. 1986; 365(2): 211-27. PubMed Abstract | Publisher Full Text

15. Fetz EE, Cheney PD: Postspike facilitation of forelimb muscle activity by primate corticomotoneuronal cells. J Neurophysiol. 1980; 44(4): 751-72. PubMed Abstract | Publisher Full Text

16. Lemon RN, Mantel GW, Muir RB: Corticospinal facilitation of hand muscles 
during voluntary movement in the conscious monkey. J Physiol. 1986; $\mathbf{3 8 1}$ : 497-527.

PubMed Abstract | Publisher Full Text | Free Full Text

17. Schieber MH: Dissociating motor cortex from the motor. J Physiol. 2011; 589(Pt 23): 5613-24.

PubMed Abstract | Publisher Full Text | Free Full Text

18. Bennett KM, Lemon RN: The influence of single monkey cortico-motoneuronal cells at different levels of activity in target muscles. J Physiol. 1994; 477(Pt 2): 291-307.

PubMed Abstract | Publisher Full Text | Free Full Text

19. Griffin DM, Hudson HM, Belhaj-Saïf A, et al:: Do corticomotoneuronal cells predict target muscle EMG activity? J Neurophysiol. 2008; 99(3): 1169-986. PubMed Abstract | Publisher Full Text

20. Muir RB, Lemon RN: Corticospinal neurons with a special role in precision grip. Brain Res. 1983; 261(2): 312-6.

PubMed Abstract | Publisher Full Text

21. Buys EJ, Lemon RN, Mantel GW, et al:: Selective facilitation of different hand muscles by single corticospinal neurones in the conscious monkey. J Physiol. 1986; 381: 529-49.

PubMed Abstract | Publisher Full Text | Free Full Text

22. F Griffin DM, Hoffman DS, Strick PL: Corticomotoneuronal cells are "functionally tuned". Science. 2015; 350(6261): 667-70.

PubMed Abstract | Publisher Full Text | Free Full Text | F1000 Recommendation

23. Smith AM: The coactivation of antagonist muscles. Can J Physiol Pharmacol. 1981; 59(7): 733-47.

PubMed Abstract | Publisher Full Text

24. Quallo MM, Kraskov A, Lemon RN: The activity of primary motor cortex corticospinal neurons during tool use by macaque monkeys. $J$ Neurosci. 2012 32(48): 17351-64.

PubMed Abstract | Publisher Full Text | Free Full Text

25. Griffin DM, Hudson HM, Belhaj-Saif A, et al.: Hijacking cortical motor output with repetitive microstimulation. J Neurosci. 2011; 31(37): 13088-96. PubMed Abstract | Publisher Full Text | Free Full Text

26. Maier MA, Kirkwood PA, Brochier T, et al:: Responses of single corticospinal neurons to intracortical stimulation of primary motor and premotor cortex in the anesthetized macaque monkey. J Neurophysiol. 2013; 109(12): 2982-98. PubMed Abstract | Publisher Full Text | Free Full Text

27. Park MC, Belhaj-Saiif A, Cheney PD, et al:: Properties of primary motor cortex output to forelimb muscles in rhesus macaques. J Neurophysiol. 2004; 92(5): 2968-84.

PubMed Abstract | Publisher Full Text

28. Hudson HM, Park MC, Belhaj-Saïf A, et al:: Representation of individual forelimb muscles in primary motor cortex. J Neurophysiol. 2017; 118(1): 47-63. PubMed Abstract | Publisher Full Text | Free Full Text

29. Boudrias $\mathrm{MH}, \mathrm{McPherson} \mathrm{RL}$, Frost $\mathrm{SB}$, et al:: Output properties and organization of the forelimb representation of motor areas on the lateral aspect of the hemisphere in rhesus macaques. Cereb Cortex. 2010; 20(1): 169-86. PubMed Abstract | Publisher Full Text | Free Full Text

30. Boudrias MH, Lee SP, Svojanovsky S, et al.: Forelimb muscle representations and output properties of motor areas in the mesial wall of rhesus macaques. Cereb Cortex. 2010; 20(3): 704-19.

PubMed Abstract | Publisher Full Text | Free Full Text

31. Firmin L, Field P, Maier MA, et al:: Axon diameters and conduction velocities in the macaque pyramidal tract. $J$ Neurophysiol. 2014; 112(6): 1229-40. PubMed Abstract | Publisher Full Text | Free Full Text

32. Leenen LP, Meek J, Posthuma PR, et al:: A detailed morphometrical analysis of the pyramidal tract of the rat. Brain Res. 1985; 359(1-2): 65-80. PubMed Abstract | Publisher Full Text

33. Venkadesan M, Valero-Cuevas FJ: Neural control of motion-to-force transitions with the fingertip. J Neurosci. 2008; 28(6): 1366-73.

PubMed Abstract | Publisher Full Text | Free Full Text

34. Perge JA, Niven JE, Mugnaini E, et al:: Why do axons differ in caliber? J Neurosci. 2012; 32(2): 626-38.

PubMed Abstract | Publisher Full Text | Free Full Text

35. Quencer RM, Bunge RP, Egnor M, et al:: Acute traumatic central cord syndrome: MRI-pathological correlations. Neuroradiology. 1992; 34(2): 85-94. PubMed Abstract | Publisher Full Text

36. Blight AR: Morphometric analysis of a model of spinal cord injury in guinea pigs, with behavioral evidence of delayed secondary pathology. J Neurol Sci. 1991; 103(2): 156-71.

PubMed Abstract | Publisher Full Text

37. F Innocenti GM, Caminiti R, Rouiller EM, et al.: Diversity of Cortico-descending Projections: Histological and Diffusion MRI Characterization in the Monkey. Cereb Cortex. 2019; 29(2): 788-801.

PubMed Abstract | Publisher Full Text | F1000 Recommendation

38. Humphrey DR, Corrie WS, Rietz R: Properties of the pyramidal tract neuron system within the precentral wrist and hand area of primate motor cortex. J Physiol (Paris). 1978; 74(3): 215-26. PubMed Abstract

39. Kraskov A, Baker S, Soteropoulos D, et al.: The Corticospinal Discrepancy: Where are all the Slow Pyramidal Tract Neurons? Cereb Cortex. 2018. PubMed Abstract | Publisher Full Text

40. Lemon RN: Descending pathways in motor control. Annu Rev Neurosci. 2008;
31: 195-218.

PubMed Abstract | Publisher Full Text

41. Lemon RN: What drives corticospinal output? F1000 Biol Rep. 2010; 2: 51 PubMed Abstract | Publisher Full Text | Free Full Text

42. Tower SS: Pyramidal Lesion In The Monkey. Brain. 1940; 63(1): 36-90. Publisher Full Text

43. Lawrence DG, Kuypers HG: The functional organization of the motor system in the monkey. I. The effects of bilateral pyramidal lesions. Brain. 1968; 91(1): $1-14$

PubMed Abstract | Publisher Full Text

44. Lemon RN, Landau W, Tutssel D, et al.: Lawrence and Kuypers (1968a, b) revisited: copies of the original filmed material from their classic papers in Brain. Brain. 2012; 135(Pt 7): 2290-5.

PubMed Abstract | Publisher Full Text

45. Isa T, Kinoshita M, Nishimura Y: Role of Direct vs. Indirect Pathways from the Motor Cortex to Spinal Motoneurons in the Control of Hand Dexterity. Front Neurol. 2013; 4: 191 .

PubMed Abstract | Publisher Full Text | Free Full Text

46. F Freund $P$, Schmidlin $E$, Wannier $T$, et al:: Nogo-A-specific antibody treatment enhances sprouting and functional recovery after cervical lesion in adult primates. Nat Med. 2006; 12(7): 790-2.

PubMed Abstract | Publisher Full Text | F1000 Recommendation

47. F Kinoshita M, Matsui R, Kato S, et al.: Genetic dissection of the circuit for hand dexterity in primates. Nature. 2012; 487(7406): 235-8. PubMed Abstract | Publisher Full Text | F1000 Recommendation

48. F Tohyama T, Kinoshita M, Kobayashi K, et al:: Contribution of propriospinal neurons to recovery of hand dexterity after corticospinal tract lesions in monkeys. Proc Natl Acad Sci U S A. 2017; 114(3): 604-9.

PubMed Abstract | Publisher Full Text | Free Full Text | F1000 Recommendation

49. Lemon RN, Kirkwood PA, Maier MA, et al.: Direct and indirect pathways for corticospinal control of upper limb motoneurons in the primate. Prog Brain Res. (Mori S, Stuart DG, Wiesendanger M, eds) Amsterdam: Elsevier. 2004; 263-279.

PubMed Abstract | Publisher Full Text

50. F Riddle CN, Edgley SA, Baker SN: Direct and indirect connections with upper limb motoneurons from the primate reticulospinal tract. $J$ Neurosci. 2009; 29(15): 4993-9.

PubMed Abstract | Publisher Full Text | Free Full Text | F1000 Recommendation

51. Baker SN: The primate reticulospinal tract, hand function and functional recovery. J Physiol. 2011; 589(Pt 23): 5603-12.

PubMed Abstract | Publisher Full Text | Free Full Text

52. Krakauer JW, Carmichael ST: Broken Movement. The Neurobiology of Motor Recovery After Stroke. MIT Press. 2017.

Reference Source

53. F Azim E, Jiang J, Alstermark B, et al.: Skilled reaching relies on a V2a propriospinal internal copy circuit. Nature. 2014; 508(7496): 357-63. PubMed Abstract | Publisher Full Text | Free Full Text | F1000 Recommendation

54. F Gu Z, Kalambogias J, Yoshioka S, et al.: Control of species-dependent cortico-motoneuronal connections underlying manual dexterity. Science. 2017; 357(6349): 400-4.

PubMed Abstract | Publisher Full Text | Free Full Text | F1000 Recommendation

55. Schmidlin E, Kaeser M, Gindrat AD, et al:: Behavioral assessment of manual dexterity in non-human primates. J Vis Exp. 2011; (57): pii: 3258.

PubMed Abstract | Publisher Full Text | Free Full Text

56. Maeda H, Fukuda S, Kameda H, et al.: Corticospinal axons make direct synaptic connections with spinal motoneurons innervating forearm muscles early during postnatal development in the rat. J Physiol. 2016; 594(1): 189-205. PubMed Abstract | Publisher Full Text | Free Full Text

57. Eisen A, Turner MR, Lemon R: Tools and talk: an evolutionary perspective on the functional deficits associated with amyotrophic lateral sclerosis. Muscle Nerve. 2014; 49(4): 469-77.

PubMed Abstract | Publisher Full Text

58. Eisen $\mathrm{A}$, Braak $\mathrm{H}$, Del Tredici $\mathrm{K}$, et al:: Cortical influences drive amyotrophic lateral sclerosis. J Neurol Neurosurg Psychiatry. 2017; 88(11): 917-24. PubMed Abstract | Publisher Full Text

59. Clough JF, Kernell D, Phillips CG: The distribution of monosynaptic excitation from the pyramidal tract and from primary spindle afferents to motoneurones of the baboon's hand and forearm. J Physiol. 1968; 198(1): 145-66. PubMed Abstract | Publisher Full Text | Free Full Text

60. Barthélemy D, Grey MJ, Nielsen JB, et al.: Involvement of the corticospinal tract in the control of human gait. Prog Brain Res. 2011; 192: 181-97. PublMed Abstract | Publisher Full Text

61. Simonyan K: The laryngeal motor cortex: its organization and connectivity. Curr Opin Neurobiol. 2014; 28: 15-21.

PubMed Abstract | Publisher Full Text | Free Full Text

62. F Braak H, Brettschneider J, Ludolph AC, et al.: Amyotrophic lateral sclerosis-a model of corticofugal axonal spread. Nat Rev Neurol. 2013; 9(12): 708-14. PubMed Abstract | Publisher Full Text | Free Full Text | F1000 Recommendation

63. Soares D, Goldrick I, Lemon RN, et al.: Expression of Kv3.1b potassium channel is widespread in macaque motor cortex pyramidal cells: A histological comparison between rat and macaque. J Comp Neurol. 2017; 525(9): 2164-74. PubMed Abstract | Publisher Full Text | Free Full Text 


\section{Open Peer Review}

\section{Current Peer Review Status:}

\section{Editorial Note on the Review Process}

Faculty Reviews are review articles written by the prestigious Members of Faculty Opinions. The articles are commissioned and peer reviewed before publication to ensure that the final, published version is comprehensive and accessible. The reviewers who approved the final version are listed with their names and affiliations.

\section{The reviewers who approved this article are:}

\section{Version 1}

\section{Robert J. Morecraft}

Laboratory of Neurological Sciences, School of Medicine, University of South Dakota, Vermillion, SD, USA

Competing Interests: No competing interests were disclosed.

\section{Eric Schmidlin}

Department of Neurosciences and Movement Sciences, Section of Medicine, Faculty of Sciences and Medicine, Fribourg Center of Cognition, University of Fribourg, Fribourg, Switzerland

Competing Interests: No competing interests were disclosed.

The benefits of publishing with F1000Research:

- Your article is published within days, with no editorial bias

- You can publish traditional articles, null/negative results, case reports, data notes and more

- The peer review process is transparent and collaborative

- Your article is indexed in PubMed after passing peer review

- Dedicated customer support at every stage

For pre-submission enquiries, contact research@f1000.com 